Al-Manhaj: Jurnal Hukum dan Pranata Sosial Islam

Vol. : : 1 (2), 2019, 229-256

P-ISSN : 2686-1607

E-ISSN : 2686-4819

\title{
TINJAUAN MAQASHID SYARI'AH TERHADAP AKIBAT TINDAKAN MARITAL RAPE DALAM UU NO.23 TH. 2014 DAN RUKHP
}

\author{
Diyan Putri Ayu \\ Institut Agama Islam Sunan Giri Ponorogo \\ email: diyan_Pa@yahoo.co.id
}

\begin{abstract}
Marriage is a strong contract (mitsaqan Ghalidzan), containing transcendental values (divine), carried out consciously by men and women to form a family whose implementation is based on willingness and agreement between the two. Understanding that a woman (wife) under any circumstances must fulfill her husband's sexual desires and if the wife refuses her husband's sexual invitation, then he is said to be a great sinner often used as a legitimate tool in the name of religion. Thus, it becomes natural if then the husband's sexual coercion of his wife which should be between each other intercourse in ways that are ma'ruf and loving. Given this reality, the author will discuss the main problem is the analysis of Maqashid Shari'ah on the effects of marital rape in Law No.23 Th. 2014 and RUKHP. The results of the analysis explained that in an effort to deal with the wife of a victim of domestic violence must be in line with the objectives of Islamic law, namely the protection of the 5 main principles in Islam, namely maintaining religion, life, reason, descent and wealth.
\end{abstract}

Keywords: Maqashid Syari'ah, Marital Rape dan UU KDRT

Abstrak: Perkawinan merupakan akad yang kuat (mitsaqan Ghalidzan), mengandung nilai-nilai transendetal (ilahiyah), dilakukan secara sadar oleh laki-laki dan perempuan guna membentuk keluarga yang pelaksanaanya didasarkan pada kerelaan dan kesepakatan diantara keduanya. Pemahaman bahwa wanita (istri) dalam keadaan apapun harus memenuhi keinginan seksual suaminya dan jika istri menolak ajakan seks suaminya, maka ia dikatakan berdosa besar kerap kali dijadikan alat legitimasi atas nama agama. Dengan demikian, menjadi wajar jika kemudian terjadi pemaksaan seksual suami terhadap istri yang 
seharusnya diantara keduanya saling menggauli dengan cara-cara yang ma'ruf dan penuh kasih sayang. Dengan adanya kenyataan inilah, maka penulis akan membahas Pokok permasalahanya adalah analisis Maqashid Syari'ah terhadap akibat tindakan marital rape dalam UU No.23 Th. 2014 dan RUKHP. Hasil analisis mejelaskan bahwa dalam upaya penanganan istri korban kekerasan dalam rumah tangga harus sejalan dengan tujuan hukum islam yakni perlindungan terhadap terjaminya 5 prinsip utama dalam islam yakni memelihara agama,jiwa, akal, keturunan dan harta.

Kata Kunci: Maqashid Syari'ah, Marital Rape dan UU KDRT

\section{PENDAHULUAN}

Ulama' ushul fiqih mendefinisikan Maqashid Syari'ah dengan makna dan tujuan yang dikehendaki syara' dalam mensyari'atkan suatu hukum bagi kemaslahatan umat manusia . Maqashid Syari'ah dikalangan ulama' ushul fiqih disebut juga asrar al-Syari'ah, yaitu rahasia-rahasia yang terdapat dibalik hukum yang diterapkan oleh syara' mewajibkan berbagai macam ibadah dengan tujuan menegakkan agama Allah.

Sementara menurut Wahbah al Zuhaili, Maqashid Syari'ah berarti nilai-nilai dan sasaran syara' yang tersirat dalam segenap atau bagian terbesar dari hukum-hukumnya. Nilai-nilai dan sasaran itu dipandang sebagai tujuan dan rahasia syari'ah, yang ditetapkan oleh al-Syar'I dalam setiap ketentuan hukum. Menurut Syatibi tujuan akhir hukum tersebut adalah satu, yaitu maslahat atau kebaikan dan kesejahteraan umat manusia. ${ }^{1}$

Belakangan ini marak pembahasan dalam RKUHP yang isinya tentang kekerasan pemerkosaan dalam Rumah Tangga, karena itu perlu dibahas hukumnya menurut syari'ah islam. Kajian ini dianggap semakin penting setelah ada gejolak perbedaan pendapat setuju dan tidak setuju

${ }^{1}$ Ahmad Musyahid Idrus, Urgensi Filsafat Hukum Islam dalam Penetapan Hukum Islam: Kajian Filosofis Terhadap Persoalan Hukum Kontemporer (Makasar: Allauddin University Press, 2014), 76. 
disahkanya UU Pidana tersebut. Dimana UU tersebut dianggap terlalu membatasi perilaku suami istri dalam menjalankan hak dan kewajibanya dalam menaungi Rumah Tangga.

Keseimbangan antara hak dan kewajiban suami istri serta hidup damai dalam rumah tangga adalah sesuatu yang pasti sangat diidamkan oleh setiap pasangan suami istri, akan tetapi semua impian tersebut akan berubah menjadi kenyataan yang menyakitkan apabila didalamnya ternyata dinodai dengan adanya tindak kekerasan dalam rumah tangga. Di dalam bukunya, Zainuddin Ali menyebutkan bahwa perkawinan adalah perbuatan hukum yang mengikat antara seorang pria dan seorang wanita (suami istri) yang mengandung nilai ibadah kepada Allah disatu pihak, dan di pihak lainya mengandung aspek keperdataan yang menimbulkan hak dan kewajiban antar suami dan istri. ${ }^{2}$ Perkawinan merupakan suatu jalan utama untuk mengatur kehidupan rumah tangga dan keturunan. Keeratan dan keharmonisan hubungan keduanya itu akan terwujud jika keduanya menjalankan kewajiban sebagai suami istri.

Pada prinsipnya, dalam hubungan seksual suami istri memiliki hak yang sama (keseimbangan antara hak dan kewajiban suami istri). Idealnya adalah persetubuhan yang bisa dinikmati oleh keduanya dengan kepuasan nafsu "birahi" sebagai manusia yang adil dan merata. Bukan persetubuhan yang dipaksakan oleh salah satu pasanganya baik dalam hal ini seorang suami, sementara seorang istri dalam keadaan capek, sakit, tidak berselera, bahkan bisa jadi ketika datang bulan.

Selama ini kekerasan seksual yang dilakukan suami terhadap istri (marital rape) sangat jarang mendapatkan perhatian dikalangan masyarakat. Suami yang memaksakan sebuah aktifitas senggama, jarang dimunculkan ke permukaan oleh istrinya. Lemahnya kedudukan istri dalam keluarga dan masyarakat menjadi salah satu penyebab. Lebih-

2 Zainuddin Ali, Hukum Perdata Islam di Indonesia, (Jakarta: Sinar Grafika,2006), 51. 
lebih peran public, yang berasumsi laki-laki mempunyai hak otonom di dalam keluarga. Pasalnya membuat laki-laki merasa berhak melakukan apa saja terhadap wanita. Parahnya, kebanyakan dari kaum laki-laki menganggap perkawinan adalah legitimasi resmi atas kekuasaanya terhadap kaum perempuan.

Dalam UU No.23 Tahun 2004 sudah dijelaskan aturanya secara jelas, terkait dengan marital rape sebagai pemerkosaan terhadap perempuan. Akan tetapi, sangat ironis pelaku kekerasan seksual terhadap istri yang terjadi di masyarakat hanya dijerat dengan pasal 351,353, dan pasal 356 tentang penganiayaan. Hukuman yang lebih ringan jika digolongkan kedalam delik pemerkosaan. Pemerkosaan adalah bentuk kekerasan terberat yang dirasakan oleh perempuan. Yang akibatnya tidak hanya berdampak pada rusaknya organ fisik tapi juga psikis.

Menurut Jhonson dan Sacco,kekerasan terhadap perempuan (seksual) yang dilakukan oleh suami atau pasangan intimnya (intimate partner violence) dikenal dengan istilah kekerasan terhadap istri (wife abuse). Kasus pemerkosaan terhadap perempuan tidak hanya terjadi di luar perkawinan, di dalam perkawinan pun juga kerap terjadi. Terutama pemerkosaan yang dilakukan oleh suami terhadap istri. Salah satu bentuk perihal kekerasan dalam rumah tangga yang paling rawan terjadi yaitu kekerasan seksual terhadap istri atau yang lebih dikenal dengan istilah Marital Rape. Dalam undang-undang KDRT pasal 1 ayat 1 disebutkan bahwa kekerasan dalam rumah tangga adalah setiap perbuatan terhadap seseorang terutama perempuan, yang berakibat timbulnya kesengsaraan atau penderitaan secara fisik, seksual, 
psilokogis, dan atau perampasan kemerdekaan secara melawan hukum dalam lingkup rumah tangga. ${ }^{3}$

Pemaksaan hubungan seksual dalam rumah tangga jelas telah melanggar hak istri, karena seks adalah juga haknya. Aktivitas seksual yang didasari oleh pemaksaan (pemerkosaan) menyebabkan hanya pihak suami saja yang dapat menikmati, sedang istri tidak sama sekali, bahkan tersakiti. Tanpa kehendak dan komunikasi yang baik antara suami dan istri, mustahil terjadi keselarasan akses kepuasaan. Hubungan seks yang dilakukan di bawah tekanan atau pemaksaan sama halnya dengan penindasan perempuan yang secara berulang dan berkelanjutan menjadi korban pemerkosaan suaminya akan terjangkiti beberapa karakter, antara lain: pertama, inferior (merasa rendah diri) dan tidak percaya diri, kedua, kerap dan selalu merasa bersalah sebab ia membuat suami "kalap" dan ketiga, menderita gangguan reproduksi akibat perasaan tertekan atau stres, seperti infertilitas (kurang mampu menghasilkan keturunan) dan kacaunya siklus haid. Hal yang demikian itu,apakah publik (masyarakat) akan (masih) memandang sebelah mata dengan kasus Marital Rape (kekerasan seksual terhadap istri). Sementara kaum perempuan terus akan dirugikan dan dilukai, fisik maupun psikisnya. Berangkat dari problematika social inilah di mana seringkali terjadi bentuk-bentuk kekerasan seksual yang dilakukan oleh seorang suami terhadap isteri yang semestinya masuk dalam koridor tindakan kriminal, namun selalu berlindung dalam konsep agama dan adat.

\section{HAKIKAT MAQASHID AL-SYARI'AH}

Secara Lughawi (bahasa), Maqasid al-Syariah terdiri dari dua kata, yakni Maqasid dan Syariah. Maqasida adalah bentuk jama' dari

3 Elli Nurhayati, Panduan untuk Pendamping Korban Kekerasan (Yokyakarta: Rifka Anisa, 2000), 28. 
maqsuudu yang berarti kesengajaan atau tujuan. Syari'ah berarti secara bahasa jalan menuju sumber air. Jalan menuju sumber air ini dapat pula dikatakan sebagai jalan kearah sumber pokok kehidupan. ${ }^{4}$

Makna Maqasid al-Syariah menurut Abdullah Yusuf Ali, dalam The Holly Quran, Syari'ah adalah segala apa yang digunakan atau ditetapkan oleh Allah SWT dalam agama untuk pengaturan hidup hambahambaNya ${ }^{5}$. Akhmad al-Raisuni dalam Nazhariyat al-Maqashid 'Inda alSyatibi, dari segi bahasa Maqasid al-Syari'at berarti maksud atau tujuan disyari'atkan hukum Islam, karena itu yang menjadi bahasan utama di dalamnya adalah mengenai masalah hikmat dan ilat ditetapkannya suatu hukum. ${ }^{6}$ Kandungan Maqasid al-Syariah atau tujuan hukum adalah kemaslahatan umat manusia. ${ }^{7}$ Kemaslahatan itu, melalui analisis Maqasid al-Syariah tidak hanya dilihat dalam arti teknis belaka, akan tetapi dalam upaya dinamika dan pengembangan hukum dilihat sebagai sesuatu yang mengandung nilai filosofis dari hukum-hukum yang disyariatkan Tuhan terhadap manusia. ${ }^{8}$ Dengan demikian Maqasid al-Syariah dapat dimaknai dengan "tujuan Allah dan Rasul-Nya dalam merumuskan syari'at Islam". Yang tiada lain selain untuk mengambil kemaslahatan dan menghindari kemadharatan manusia itu sendiri, baik di dunia maupun di akhirat. ${ }^{9}$

Dasar dari Maqasid Syariah adalah sebagaimana disebutkan dalam QS. Al-Jaatsiyah, ayat 18, yang artinya, "Kemudian Kami jadikan kamu berada di atas suatu syariat (peraturan) dari urusan (agama itu), Maka ikutilah syariat itu dan janganlah kamu ikuti hawa nafsu orang-

${ }^{4}$ Ahmad Imam Mawardi. Fiqh Minoritas fiqhal-Aqlliyat dan Evolusi Maqashid alSyari'ah dari Konsep Kependekatan (Yogyakarta: Lkis, 2010), 178-179.

${ }^{5}$ Asafri Jaya Bakri, Konsep Maqashid al-Syari'ah Menurut al-Syatibi (Jakarta: PT Raja Grafindo, 1996), 61. 1999), 123.

6 Fathurrahman Djamil, Filsafat Hukum Islam (Jakarta: Logos Wacana Ilmu,

${ }^{7}$ Asafri Jaya Bakri, Konsep Maqashid al-Syari'ah Menurut al-Syatibi, 64.

8Bakri,65.

${ }^{9}$ Fathurrahman Djamil, Filsafat Hukum, 135. 
orang yang tidak mengetahui."(Q.S. Al-Jatsiyyah:18). Dan juga dalam QS. Al-Syuraa, ayat 13 juga di tegaskan yang Artinya: "Dia telah mensyari'atkan bagi kamu tentang agama apa yang telah diwasiatkanNya kepada Nuh dan apa yang telah Kami wahyukan kepadamu dan apa yang telah Kami wasiatkan kepada Ibrahim, Musa dan Isa Yaitu: Tegakkanlah agama dan janganlah kamu berpecah belah tentangnya. Amat berat bagi orang-orang musyrik agama yang kamu seru mereka kepadanya. Allah menarik kepada agama itu orang yang dikehendakiNya dan memberi petunjuk kepada (agama)-Nya orang yang kembali (kepada-Nya)."10

Maqasid Syariah adalah suatu konsep yang menekankan tujuan penetapan hukum Islam dalam upaya memelihara kemaslahatan hidup manusia, dengan tujuan mendatangkan kemanfaatan dan menghindarkan diri dari bahaya. Ibnu al-Qayyim al-Jauziyyah, mengatakan bahwa sesungguhnya prinsip-prinsip dan dasar pendapatan hukum Islam adalah demi kemaslahatan hamba di dunia dan di akhirat. Menurutnya, hukum Islam itu semuanya adil, membawa rahmat, mengandung maslahat dan membawa hikmah. Imam al-Ghazali, berpendapat, bahwa maslahat pada dasarnya adalah ungkapan dari memperoleh manfaat dan menolak mudharat. Ungkapan tersebut dikategorikan sebagai kaidah yang paling luas, ruang lingkup dan cakupannya. ${ }^{11}$ Para ulama mengemukakan, bahwa ada tiga macam tujuan syarī'ah atau tingkatan Maqasid yaitu Maqasid al-Syariah, Maqasid al-Hajiat Maqasid al-Tahsiniyat

\section{MAQASID AL-SYARIAH}

Imam Juwayniy telah mengemukakan, yang kemudian dikembangkan oleh Al-Ghozali dan asy-Syatibi untuk memelihara al-

${ }^{11}$ Asafri Jaya Bakrie, Konsep Maqashid al-Syari'ah Menurut al-Syatibi, 61-62. 
Umurdh-dharuriyah dalam kehidupan manusia, yaitu hal-hal yang menjadi sendi eksistensi kehidupan manusia yang harus ada kemaslahatan pada mereka. Yaitu semua syariat yang tercakup dalam lima hal, al-kulliyyat al-khams. ${ }^{12}$ Hukum-hukum untuk memelihara alUmurdh-dharuriyah Yaitu13:

1. Hifz al-din (perlindungan terhadap agama). Untuk menegakkan agama Islam mewajibkan iman, terutama rukun iman yang enam dan mensyariatkan hukum-hukum yang berkaitan dengan rukun Islam yang lima.

2. Hifz al-nafs (perlindungan terhadap jiwa). Untuk memelihara jiwa, Islam memerintahkan makan dan minum, memakai pakaian dan bertempat tinggal sekedar cukup untuk memeliharadari kebinasaan. Begitu pula Islam mensyariatkan hukum qishash, diyat,dan kifarat bagi orang yang dengan sengaja melakukan pembunuhan, danmenyiksa tubuh. Semua hal tersebut adalah untuk menghindarkan kemudharatan yang mengancam jiwa.

3. Hifz al-aql (perlindungan terhadap akal). Untuk memelihara akal, Islam mengharamkan khamar dan segala Jenis makanan dan minum yang memabukan karena merusak akal, serta memberikan hukuman kepada peminum khamar. Islam juga Menjamin kreatifitas berfikir dan mengeluarkan pendapat.

4. Hifz al-mal (perlindungan terhadap harta benda). Untuk memelihara harta, Islam mengharamkan mencuri, menipu, menjalankan dan memakan riba, merusak harta baik milik sendiri maupun milik orang lain. Untuk memperoleh harta disyaratkan usaha-usaha yang halal,

12Bakrie.

${ }^{13}$ Asmuni Mth, "Upaya Pemikiran Al-Maqashid (Upaya Menemukan Fondasi Ijtihad Akademik yang Dinamis)", Al Mawarid, Edisi XIV, (2005), 158. Ahmad Imam Mawardi, Fiqh Minoritas fiqhal-Aqlliyat dan Evolusi Maqashid al-Syari'ah dari Konsep Kependekatan,191-192 
seprti bertani, berdagang, mengelola industri, dan lain sebagainya.

5. Hifz al-nasl wa al-ird (perlindungan terhadap kehormatan dan keturunan). Untuk memelihara kehormatan/ keturunan, Islam mensyariatkan hukuman badan (had) bagi orang yang berzina dan orang yang menuduh orang baik-baik berbuat zina. Untuk memelihara keturunan, Islam mensyaratkan hukum perkawinan agar manusia berkembang biak dalam keadaan yang sebaik-baiknya. Islam juga melarang menghina dan melecehkan orang lain di hadapan umum Islam menjamin kehormatan manusia dengan memberikan perhatian yang sangat besar, yang dapat digunakan untuk memberikan spesialisasi kepada hak asasi mereka. Islam juga memberikan perlindungan melalui pengharaman ghibah (menggunjing), mengadu domba, memata-matai, mengumpat, dan mencela dengan menggunakan panggilan-panggilan buruk, juga perlindungan-perlindungan lain yang bersinggungan dengan kehormatan dan kemuliaan manusia. ${ }^{14}$

\section{MAQASID AL-HAJIAT}

Untuk memenuhi dalam kehidupan manusia untuk menghilangkan kesulitan-kesulitan dan menolak halangan. Sesuatu yang dibutuhkan manusia untuk mempermudah mencapai kepentingankepentingan jika tidak ada akan akan terjadi ketidak sempurnaan. Prinsip utama dalam mewujudkan hal-hal yang hajiyat ini adalah untuk menghilangkan kesulitan, meringankan beban dan memudahkan manusia bermuamalat dan tukar menukar manfaat. 15

Dalam bidang ibadat, Islam memberikan rukhsah dan keringanan bila menjalankan kewajiban. Misalnya di bolehkan seseorang tidak puasa pada bulan ramadhan, karena ia sakit atau dalam perjalanan; 
diperbolehkan mengqasar sholat yang empat rakaat bagi orang yang sedang dalam perjalanan; diperbolehkan tayamum bagi orang yang tidak mendapatkan air atau tidak dapat menggunakannya, dibolehkan shalat sambil duduk bagi orang yang tidak sanggup melaksanakannya sambil berdiri, serta diperbolehkannya mengeluarkan pendapat atas kejadian yang menimpanya demi kebaikan semua orang dan lain sebagainya. ${ }^{16}$

\section{MAQASID AL-TAHSINIYAT}

Merupakan tindakan dan sifat yang harus dijauhi oleh akal yang sehat, dipegangi oleh adat kebiasaan yang bagus dan dihajati oleh kepribadian yang kuat. Hal-hal yang tahsini bagi manusia pada hakikatnya kembali kepada prinsip memperbaiki keadaan manusia menjadi sesuatu dengan muru'ah (hakikat diri) dan akhlak yang mulia. Dalam bidang ibadat misalnya, disyariatkan berhias dan berpakaian bersih serta bagus ketika pergi ke mesjid, menjalankan amalan-amalan sunat, bersedekah, yang kesemuanya itu untuk membiasakan manusia dengan kebiasaan-kebiasaan yang baik. ${ }^{17}$

\section{METODE PENETAPAN MAQASHID SYARI'AH}

Perbedaan mengenai Maqashid Syari'ah ini tidak saja terkait dengan kehujjahan Maqashid Syari'ah sebagai sumber pengembangan hukum. Metode-metode pengembangan hukum islam yang berdasarkan atas Maqashid Syari'ah seperti istihsan dan maslahat mursalah. Bagi Abdul Wahab Khallaf, Maqashid Syari'ah adalah suatu alat bantu untuk memahami redaksi al-Qur'an dan al-Hadits, menyelesaikan dalil-dalil yang bertentangan dan menetapkan hukum terhadap yang tidak tertampung dalam al-Qur'an. Maksudnya disini adalah manunjukkan 
Maqashid al-Syari'ah tidaklah mandiri sebagai dalil hukum tetapi merupakan dasar bagi penetapan hukum melalui beberapa metode pengambilan hukum. Namun begitu hamper semua metode dipertentangkan/tidak disepakati oleh ulama', karena faKtor teologi.

Dalam pengetahuan Maqashid Syari'ah, menurut al syatibi terbagi kedalam 3 kelompok dengan metode pemahaman yang berbedabeda, yakni : Pertama, ulama yang berpendapat bahwa maqashid al syariah adalah suatu sesuatu yang abstrak, tidak dapat diketahui kecuali lewat petunjuk Tuhan yang terungkap dalam bentuk zahir lafal yang jelas. Petunjuk itu tidak memerlukan penelitian, yang pada gilirannya akan bertentangan dengan kehendak bunyi lafal. Kelompok itu disebutl al-Zahiriyah.

Kedua, ulama yang tidak menempuh pendekata zahir lafal nash. Kelompok itu terbagi menjadi dua golongan. Golongan pertama berpendapat bahwa maqashid al-syari'ah diketahui bukan dari zahir lafal dan bukan pula dari tunjukan zahir lafal. Maqashid al-syari'ah merupakan hal lain yang ada di balik tunjukan zahir yang terdapat dalam semua aspek syari'at. Kelompok itu disebut ulama al-Batiniyyah. Golongan kedua berpendapat bahwa maqashid al-syari'ah harus dikaitkan dengan pengetian zahir lafal. Artinya zahir lafal tidak harus mngandung tunjukan mutlak. Apabila terdapat pertentangan zahir lafal dengan nalar, maka yang diutamakan dan didahulukan adalah pengertian nalar, baik atas dasar keharusan menjaga kemashlahatan atau tidak. Kelompok itu disebut ulama al-Muta'ammiqin fial-Qiyas.

Ketiga, ulama yang melakukan penggabungan dan pendekatan (zahir lafal dan pertimbangan ilat) dalam suatu bentuk yang tidak merusak pengertian zahir lafal dan tidak pula merusak kandungan makna/ilat, sehingga tetap berjalan secara harmoni tanpa kontradiksi kontradiksi. kelompok itu disebut ulama al-Rasikhin. Kaitannya dengan 
hal tersebut, Imam al-syatibi dalam memahami maqashid al-syari'ah merumuskan tiga cara, yaitu:

1. Melakukan analisis terhadap lafal perintah dan larangan. Suatu perintah menurutnya menghendaki perwujudan dari sesuatu yang diperintahkan. Perwujudan isi dan perintah itu menjadi tujuan yang dikehendaki oleh alsyar'i. Demikian pula sebaliknya, sebuah larangan menghendaki suatu perbuatan yang dilarang itu ditinggalkan. Keharusan meninggalkan perbuatan yang dilarang merupakan tujuan yang diinginkan oleh Tuhan.

2. Menelaah illat al-amr (perintah) dan al-nahy (larangan). Menurutnya pemahaman maqasid al-syari'ah dapat dilakukan melalui analisis ilat hukum yang terdapat dalam Alquran dan hadits. Ilat hukum itu adakalanya tertulis secara jelas dalam ayat atau hadits, maka menurutnya, harus diikuti apa yang tertulis itu. Namun, apabila ilat tidak tertulis , maka harus dilakukan tawaqquf disini bukan bersifat pasti tetapi sebaliknya.

3. Analisis terhadap sikap diam syar'i. Ini merupakan cara memahami persoalanpersoalan hukum yang tidak disebut oleh al-syar'i.

\section{MARITAL RAPE DALAM UU N0.23 TH. 2004 DAN RKUHP}

Marital Rape adalah kosa kata inggris, gabungan dari marital berarti " segala hal yang terkait perkawinan" dan rape yang berarti "pemerkosaan". Marital rape merupakan tindak kekerasan atau pemaksaan yang dilakukan oleh suami terhadap istri untuk melakukan aktifitas seksual tanpa mempertimbangkan kondisi istri. Elli $\mathrm{N}$. Hasbianto mendefinisikan Marital Rape sebagai pemaksaan hubungan seksual tanpa memperhatikan kepuasan istri. Farha ciciek mengelompokkan marital rape kedalam 3 bagian, yaitu pemaksaan hubungan seksual ketika istri tidak siap, hubunga seksual yang diiringi 
penyiksaan dan pemaksaan hubungan seksual dengan cara yang tidak dikehendaki istri. Nurul Ilmi Idrus mendefinisikan marital rape sebagai hubungan seksual yang disertai paksaan, ancaman, pemaksaan selera sendiri dan penggunaan obat alkohol terlarang atau minuman beralkohol. ${ }^{18}$

Pemaksaan seksual yang dilakukan oleh suami terhadap istri merupakan bagian dari kekerasan seksual sebagaimana yang diakomodir oleh UU No.23 tahun 2004. Berbicara mengenai kekerasan seksual seorang suami terhadap istri tidak terleps dari perbincangan mengenai definisi kekerasan seperti yang telah dipaparkan pada bahasan sebelumnya yakni setiap perbuatan yang berupa pemaksaan hubungan seksual dengan cara tidak wajar terhadap orang lain.

1. Kekerasan terhadap perempuan adalah setiap tindakan yang melanggar, menghambat, meniadakan kenikmatan, dan pengabaian hak asasi perempuan atas gender. Tindakan tersebut mengakibatkan kerugia dan penderitaan terhadap perempuan dalam hidupnya, baik secara fisik, psikis, maupun seksual. Termasuk didalamnya ancaman, paksaan, atau perampasan kemerdekaan secara sewenang-wenang, baik dalam kehidupan individu, berkeluarga, bermasyarakat maupun bernegara.

2. Kekerasan terhadap perempuan adalah setiap perbuatan berdasarkan pembedaan jenis kelamin yang mengakibatkan kesengsaraan dan penderitaan perempuan secara fisik, seksual, atau psikologis. Termasuk ancaman tindakan tertentu, pemaksaan atau perampasan kemerdekaan secara sewenang wenang, baik dalam kehidupan publik maupun kehidupan pribadi.

18 Marlia Milda, Marital Rape Kekerasan Seksual Terhadap Istri (Yokyakarta: PT. Lkis Pelangi Aksara 2007 ), 11-13. 
3. Kekerasan tehadap perempuan adalah sebuah tindakan sosial, dimana pelakunya harus mempertanggung jawabkan tindakannya kepada masyarakat.

4. Kekerasan terhadap perempuan adalah pelaku yang muncul sebagai akibat adanya bayangan tentang peran identitas berdasarkan jenis kelamin, dan berkaitan dengan bayangan mengenai kekeuasaan yang dimilikinya. ${ }^{19}$

Kekerasan terdiri atas tindakan memaksakan kekuatan fisik dan kekuasaan kepada pihak lain. Biasanya diikuti dengan tujuan untuk mengontrol, memperlemah, bahkan menyakiti pihak lain. Tindak kekerasan terhadap perempuan meliputi berbagai fenomena, baik hukum, etika, kesehatan, budaya, politik, maupun moral. ${ }^{20}$ Tindak kekerasan terhadap perempuan pada dasarnya dapat dibagi menjadi dua kategori, yaitu kekerasan yang bersifat fisik dan nonfisik. Kekerasan fisik antara lain berupa pelecehan seksual, seperti perabaan, colekan yang tidak diinginkan, pemukulan, penganaiyaan, serta perkosaan. Termasuk dalam kategori ini adalah teror dan intimidasi, kawin paksa, kawin dibawah tangan, pelacuran paksa, stigma negatif, eksploitasi tenaga kerja, dan pemaksaan penggunaan alat kontrasepsi. Sedangkan kekerasan nonfisik antara lain berupa pelecehan seksual, seperti sapaan, siulan, colekan, atau bentuk perhatian yang tidak diinginkan, direndahkan, dianggap selalu tidak mampu, dan (istri yang) ditinggal suami tanpa kabar berita. Kekerasan terdiri dari tindakan memaksakan kekuatan fisik dan kekuasaan kepada pihak lain. Biasanya perilaku ini bertujuan untuk mengontrol, memperlemah, bahkan menyakiti pihak lain. Meski tindak kekerasan, baik berbentuk fisik maunpun nonfisi

${ }^{19}$ Marlia Milda, Marita Rape Kekrasan Seksual Terhadap Istri, 18.

20 Zaitunah Subhan, Kekerasan Terhadap Perempuan, (Yokyakarta: PT.LkiS Pelangi Aksara,t.th), h. 6-7 
keduanya menyebabkan implikasi yang serius bagi kesehatan dan mental sesorang, namun perlu diingat bahwa fenomena ini bukanlah semata persoalan keilmuan medis, melainkan melingkupi segala aspek kehidupan. ${ }^{21}$

Pada akhirnya pasal pemaksaan hubungan seksual suami terhadap istri (marital rape) dalam RUU KUHP baru tidak jadi diundangkan, karena pakar hukum yang bergabung dalam panitia khusus RUU telah sepakat untuk menghilangkan penjelasan pasal mengenai marital rape dengan alasan karena masyarakat kita belum siap menerima pasal yang controversial.

Berbeda dengan KUHP, UU No.23 Tahun 2004 tentang penghapusan kekerasan dalam rumah tangga mempunyai bentuk hukum acara yang berbeda, sehingga walaupun didalam UU tersebut tidak ada kata-kata yang menyinggung perkosaan dalam perkawinan, namun dalam UU tersebut ada kata-kata untuk kekerasan seksual yang tidak hanya terbatas pada pelaku diluar rumah tangga, namun juga pada pelaku didalam rumah tangga. UU No.23 tahun 2004 mengakui bahwa realitas pemaksaan hubungan seksual malah sering terjadi bahwa persoalan seksual dalam sebuah keluarga adalah persoalan domestik, yang publik tidak berhak untuk ikut campur. Menurut penilaian April Danarto, kaum pria lebih cenderung mengekspresikan kemarahan dan frustasi dalam bentuk-bentuk kekerasan sehingga mereka lebih dipandang sebagai pasien "akut". Kaum wanita lebih banyak didiagnosa menderita depresi. Karena bentuk-bentuk emosi relative dapat dilampiaskan lebih cepat melalui ngamuk, maka penurunan tingkat ngamuk dapat dipandang sebagai tanda "kesembuhan", sehingga pria dipulangkan lebih cepat. Ini hanya spekulasi saya. 
Namun mungkin juga pihak keluarga menginginkan kepulangan mereka karena alasan financial, karena kaum pria lebih dipandang sebagi pencari nafkah disbanding wanita. ${ }^{22}$ Dalam sisi lain, bentuk-betuk kekerasan terhadap perempuan yang tertuang dalam deklarasi penghapusan kekerasan terhadap perempuan, yang di adopsi majelis PBB tahun1993, pada pasal 2 adalah :

1. Tindak kekerasan secara fisik, seksual, dan psikologis yang terjadi dalam keluarga, termasuk pemukulan, penyalahgunaan seksual atas anak-anak perempuan dalam keluarga, kekerasan yang berhubungan dengan maskawin(mahar), perkosaan dalam perkawinan, perusakan alat kelamin perempuan, dan praktik-praktik kekejaman tradisional lain terhadap perempuan diluar hubungan suami-istri, serta kekerasan yang berhubungan dengan eksploitasi.

2. Kekerasan secara fisik, seksual, dan psikolgis yang terjadi dalam masyarakat luas termasuk perkosaan, penyalahgunaan seksual, pelecehan, dan ancaman seksual ditempat kerja, dalam lembagalembag pendidikan, dan sebagainya.

3. Kekerasan secara fisik, seksual, dan psikologis yang dilakukan atau dibenarkan oleh Negara. ${ }^{23}$

Lahirnya pemikiran ini adalah dalam rangka menjembatangi pemikiran mengenai pemaksaan istri oleh suami antara Hukum Islam dengan UU No.23 Tahun 2004 tentang pengahpusan KDRT. Kekerasan seksual adalah tiap-tiap perbuatan yang mencakup pelecehan seksual, memaksa istri baik secara fisik untuk melakukan hubungan seksual dan atau melakukan hubungan seksual tanpa persetujuan dan disaat istri tidak menghendaki, melakukan hubungan seksual dengan cara-cara yang tidak wajar atau tidak disukai istri, maupun menjauhkan atau tidak

\footnotetext{
${ }^{22}$ Apri anarto, Lanskap Hasrat dan Kekerasan (Yokyakarta: Jendela), 273

23 Fathul Djannah. Kekerasan Terhadap Istri (Yokyakarta: LkiS), 12-13.
} 
memenuhi kebutuhan seksual istri. Seks merupakan salah satu kebutuhan dasar manusia dan merupakan dasar dari sebuah perkawinan. Seks menjadi saran untuk memperoleh keturunan, kenikmatan seksual, dan kepuasan seksual. Namun bila salah satu seorang dari dua insan yang sedang melakukan hubungan seksual tidak menikmatinya, maka hubungan seksual dapat merupakan sesuatu yang ingin dihindari, bahkan dibenci. Banyak pasangan suami istri yang tidak menikmati hubungan seksual yang mereka lakukan. Seks bagi mereka dapat menjadi beban, bahkan dapat dipandang sebagai sesuatu yang harus dihindari. Hal ini terjadi karena salah satu merasa tidak diperlukan selayaknya. Satu pihak memaksakan kehendak seksualnya tanpa memperhatikan keinginan pihak lain. Pemaksaan dan ketidak acuhan terhadap hasrat dan kepuasan seksual merupakan salah satu bentuk kekerasan seksual. Bentuk-bentuk kekerasan seksual yang sering dialami antara lain: dilecehkan setelah melakukan hubungan seksual tanpa persetujuan istri, dan tidak memenuhi kebutuhan seks istri karena suami punya istri lain, serta perselingkuhan atau hubungan suami dengan perempuan lain diluar nikah. ${ }^{24}$

\section{LATAR BELAKANG PEMAKSAAN HUBUNGAN SEKSUAL SUAMI TERHADAP ISTRI}

Kekerasan terhap istri selama ini tidak pernah didefinisikan sebagai persoalan sosial. Akibatnya nyaris mustahil bagi istri meminta bantuan untuk mengatasi kekerasan suaminya. Posisi istri dalam keluarga tidak terlepas dari system sosial masyarakat yang meligkupinya, pembagian peran antara suami dan istri, sehingga menempatkan istri dalam posisi yang rentan terhadap kekerasan. Dalam keluarga, suami dianggap sebagai pusat kekuasaan dan istri harus 
berada di bawah kekuasaan suami. Istri berkawijaban menjaga harmoni dan tertib keluarga. Ironisnya, pembagian ini tidak diletakkan dalam posisi yang setara. Istri harus menopang kesuksesan karir suami, ia harus selalu bersikap lembut dan mengorbankan kepentingan pribadinya.

Persoalan akan muncul ketika suami tidak menghayati nilai cinta kasih yang sama dengan istri, rasa harga diri laki-laki sebagai kaum pemegang norma, membuatnya melihat keluarga sebagai lembaga pelestarian otoritas dan kekuasaanya, karena dalam lembaga keluargalah seorang laki-laki pertama-tama mendapatkan pengakuan akan perannya sebagai pemimpin. Laki-laki pelaku tindak kekerasan dalam rumah tangga mempertahankan daya kepemimpinanya terhadap kekeluarga dengan menggunakan kekuatan fisik untuk menunduhkan perempuan. Keberlawan titik pijak antara laki-laki dan perempuan terhadap kuasa dan control kepemimpinannya laki-laki sebagai kepala rumah tangga. 25

Di antara potensi yang diberikan oleh Allah kepada manusia adalah potensi seksual, termasuk nafsu seks. Nafsu syahwat diberikan dalam proses penciptaan manusia, oleh karenanya nafsu menjadi sesuatu yang naluriah dan alami bagi manusia. Kekerasan dalam rumah tangga terutama kekerasan pada istri tidak akan terjadi jika tidak ada penyebabnya. Di negara indonesia, kekerasan pada perempuan merupakan salah satu negatif yang tanpa disadari sebenarnya telah diturunkan secara turun temurun.

Beberapa faktor yang menyebabkan terjadinya kekerasan suami terhadap istri, antara lain: (1) Masyarakat membesarkan anak laki-laki

25 Andy Dermawan, "Marital Rape dalam Perspektif Hukum Al-Quran", Dalam Mochammad Sodik, Tela'ah Ulang Wacana Seksualitas,( Cet I. Yokyakarta : PSW IAIN Sunan Kalijaga, Depag RI Dn Mc-Gill-IISEP-CIDA,2004), 250. 
dengan menumbuhkan keyakinan bahwa anak laki-laki harus kuat, berani dan tidak toleran. (2) Laki-laki dan perempuan tidak diposisikan setara dalam masyarakat. (3) Persepsi mengenai kekerasan yang terjadi dalam rumah tangga harus ditutupi karena merupakan masalah keluarga dan bukan masalah sosial. (4) Pemahaman yang keliru terhadap ajaran agama mengenai aturan mendidik istri, kepatuhan istri pada suami, penghormatan posisi suami sehingga terjadi persepsi bahwa laki-laki boleh menguasai perempuan. (5) Budaya bahwa istri tergantung pada suami, khususnya ekonomi. (6) Kepribadian dan kondisi psikologis yang tidak stabil. (7) Pernah mengalami kekerasan pada masa kanak-kanak. (8) Budaya bahwa laki-laki dianggap superior dan perempuan inferior.

(9) Melakukan imitasi, terutama anak laki-laki yang hidup dengan orang tua sering mlakukan kekerasan pada ibunya atau dirinya. Kepribadian dan kondisi psikologis yang tidak stabil.

\section{AKIBAT PEMAKSAAN SEKSUAL TERHADAP ISTRI}

Dampak KDRT secara fisik dapat menyebabkan kecacatan yang tetap dan juga kematian, juga dapak berdampak pada psikologis dan sosial dari istri. Kekerasan psikologis dapat merusak harga diri menimbulkan kebingungan dan dapat merusak kejiwaan istri. Penganiyaan terhadap istri sering disertai pada penganiyaan pada anak. Pengaruh-pengaruh jangka panjang dari kekerasan terhadap istri sering berlanjut menjadi perlakuan kejam pada anak dan pola tersebut berlanjut dari kekerasan dalam kekeluarga menimbulkan masalah psikopatologis yang serius pada istri dan masalah-masalah lainnya dalam keluarga.

Marital Rape bisa menimbulkan lecet pada vagina istri atau luka fisik lain yang menyakiti. Ini terjadi bila saban hari suami menyetubuhi, atau hubungan tersebut berlangsung dalam waktu yang sangat lama dan 
suami sedang dalam pengaruh minuman keras, atau obat, atau suami melakukan kekerasan saat senggama. Dalam beberapa kasus, istri bahkan bisa saja mengalami memar diwajah, luka kepala, pecah bibir, patah gigi depan, dan perihya pendarahan vagina. Ini biasanya diakibatkan perlakuan kasar suami dalam sebuah hubungan seks yang dipaksakan saat istri sedang capek atau ketiduran. Akibat lain hubungan seks yang dipaksakan saat istri lelah dan capek adalah sulitnya proses persalinan, bayi lahir prematur, dan bahkan keguguran. Pada pemaksaan selera oleh pihak suami dalam hubungan seksual, akibat yang ditimbulkannya adalah luka pada dubur istri (bila hubungan itu dilakukan secara anal), muntah-muntah, penyakit kelamin menular, bahkan AIDS. Istri yang cedera fisik akibat Marital Rape biasanya tidak mau berobat kedokter ia enggan menjelaskan sebab sebenarnya dari penyakitnya karena tidak ingin kehidupan pribadi dalam keluarganya diketahui orang lain. ${ }^{26}$

Kebanyakan istri korban Marital Rape memang lebih sulit untuk mengambil keputusan buat diri sendiri. Mereka berfikir bukan hanya untuk dirinya, melainkan juga untuk anak-anak, suami, dan keluarga besarnya. Cara berfikir demikian menjadi tipikal cara berfikir perempuan (istri) sebagai akibat konstruksi yang menuntut dirinya untuk "selalu berhubungan dengan dan bertanggung jawab perempuan sebagai pihak yang diharapkan menjadi seorang ibu dan istri, pihak yang kelak bertanggung jawab penuh atas pemeliharaan anak-anak.terhadap orang lain". Konstruksi ini terkait erat dengan gender yang memosisikan.

Problem Marita Rape adalah problem kekerasan seksual suami terhadap istri yang mengarah pada tindak pemerkosaan. Sebab, pada Marital Rape tersebut terdapa unsur-unsur pemaksaan seksual 
sebagaimana pada tindak pemerkosaan reguler. Meskipun pada pemerkosaan reguler si pelaku dan si korban bukan pasangan suami istri, tetapi esensinya sama, yakni pemaksaan sebuah hubungan seksual. Jelas sudah yang melatari terjadinya kasus Marital Rape dan pula dampaknya bagi istri, anak, dan keluarga. Karena dampak fisik dan psikis Marital Rape cukup buruk, sudah saatnya masyarakat, agama, dan negara melarangnya. ${ }^{27}$

\section{ANALISIS MAQASHID SYARI'AH TERHADAP AKIBAT TINDAKAN MARITAL RAPE DALAM UU NO.23 TH. 2014 DAN RUKH}

Menimbang bahwa kehidupan manusia harus dihargai dan kekejaman dilarang, apa sudut pandang islam tentang inses dan pemerkosaan ? menurut islam, seorang wanita harus dihormati dan dilindungi dalam semua keadaan, apakah dia milik bangsa sendiri atau bangsa musuh, apakah dia mengikuti agama anda atau milik suatu agama lain atau tidak memiliki agama sama sekali. Seorang muslim tidak dapat kemarahannya dalam keadaan apapun. Semua hubungan promise cuous telah dilarang, terlepas dari status atau posisi wanita, apakah wanita tersebut adalah bersedia atau mitra tidak mau bertindak. AlQuran dalam hal ini menyebutkan di: Q.S Al-Isra/17:32.

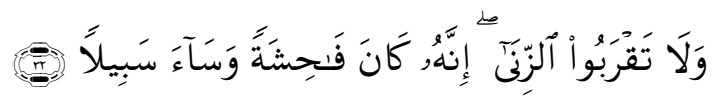

Artinya : "Dan janganlah kamu mendekati zina; Sesungguhnya zina itu adalah suatu perbuatan yang keji. Dan suatu jalan yang buruk".

Islam memandang kedudukan perempuan dan laki-laki dalam posisi yang seimbang karena pada hakikatnya semua manusia adalah sama derajat kemanusiaannya. Tidak ada kelebihan satu dibanding yang

27 Andy Dermawan, Marital Rape, 320. 
lainnya disebabkan oleh suku, ras, golongan, agama dan jenis kelamin mereka. Menurut Islam, nilai kemuliaan manusia semata-mata hanya terletak pada ketaqwaannya, Namun, berdasar pada kesadaran akan adanya perbedaan-perbedaan keduanya baik yang menyangkut masalah fisik maupun psikis, Islam kemudian membedakan keduanya dalam beberapa persoalan, terutama yang menyangkut fungsi dan peran masing-masing. Pembedaan ini dapat dikategorikan ke dalam dua hal, yaitu dalam kehidupan keluarga dan kehidupan publik. Ayat yang sering kali dijadikan dasar untuk memandang kedudukan masing-masing lakilaki dan perempuan adalah Firman Allâh pada surat al-Nisâ' [4] : 34.

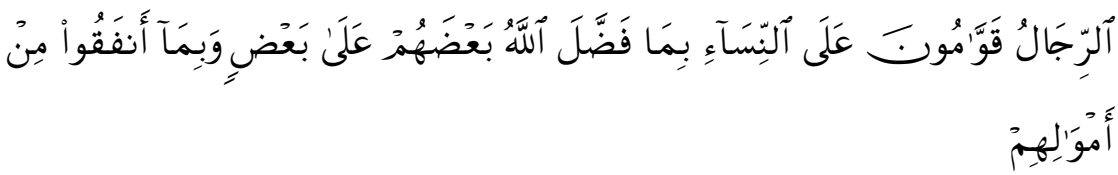

Artinya : "Kaum laki-laki adalah pemimpin bagi kaum perempuan, oleh karena Allâh telah melebihkan sebagian mereka (laki-laki) atas sebagian yang lain (perempuan), dan karena mereka (laki-laki) telah menafkahkan sebagian harta mereka"

Semua ulama sepakat bahwa ayat ini punya daya berlaku dalam konteks keluarga. Perbedaan di antara mereka baru muncul ketika ayat ini dibawa untuk di jadikan legitimasi pembedaan laki-laki dan perempuan dalam kehidupan publik. Akan tetapi, kesepakatan mereka dalam mengakui berlakunya ayat ini dalam konteks keluarga tidak kemudian berarti mereka seragam juga dalam menafsirkannya, karena perbedaan itulah maka Al-Quran memberi hak dan kewajiban masingmasing secara berbeda. Namun yang perlu ditekankan, pembedaan tersebut bukanlah diskriminasi dan wujud ketidakadilan, tetapi justru agar tercapai keseimbangan dan keharmonisan dalam menjalani bahtera rumah tangga. Dalam membedakan hak dan kewajibannya, Islam tidak memihak pada pihak laki-laki dengan menekan pihak perempuan 
sebagaimana disebutkan dalam Quran: "Dan para perempuan mempunyai hak yang seimbang dengan kewajibannya menurut cara yang ma'ruf". ${ }^{28}$

Misi pokok Al-Quran diturunkan ialah untuk membebaskan manusia dari berbagai bentuk diskriminasi dan penindasan baik yang berbasiskan etnis, budaya, politik, agama maupun gender. Meskipun Islam menjelaskan tentang persamaan kedudukan antara perempuan dengan laki-laki, namun pada kenyataannya masih sering kita dapati kondisi di mana perempuan masih belum mendapatkan hak-haknya akibat perlakuan diskriminatif yang dialaminya salah satunya yakni Kekerasan Dalam Rumah Tangga (KDRT). ${ }^{29}$

Relasi ideal antara suami dan istri dalam Islam merupakan relasi yang didasarkan pada prinsip "Mu'asharah bi al ma'ruf" (Pergaulan suami istri yang baik). Hal ini ditegaskan didalam surat an-Nisa' : 19, Allah Berfirman yang artinya, "Dan bergaulah dengan mereka (istri) dengan cara yang baik (patut). kemudian jika kamu tidak menyukai mereka, (maka bersabarlah) karena mungkin kamu tidak menyukai sesuatu, padahal Allah menjadikan padanya kebaikan yang banyak".

Ayat ini memberikan pengertian bahwa dalam sebuah perkawinan Allah menghendaki agar dibangun relasi yang kuat antara suami istri dalam pola interaksi yang positif, harmonis dengan suasana hati yang damai, yang ditandai pula oleh keseimbangan hak dan kewajiban keduanya. Keluarga sakinah tidak dapat dibangun ketika hakhak dasar pasangan suami istri dalam posisi tidak setara hal ini sering kali menyebabkan hubungan herarkis yang dapat memicu munculnya relasi kuasa yang berpeluang memegang kekuasaan menempatkan subordinasi dan marginalisasi terhadap yang dikuasai. Sesungguhnya

28 Abdurraof, Al-quran dan Ilmu Hukum (Jakarta: Bulan Bintang, 1970), 7.

29 Asy-Syaikh Abdurahman bin Nashir As-Sa'di, Taisirul Karimirrahman (Damaskus: Dar al-Fikr), 845. 
kesetaraan yang berkeadilan menghendaki sebuah relasi keluarga yang egaliter, demokratis dan terbuka yang ditandai dengan rasa saling menghormati agar terwujud sebuah komunitas yang harmonis sehingga laki-laki maupun perempuan mendapatkan hak-hak dasarnya sebagai manusia, memperoleh penghargaan dan terjaga harkat dan martabatnya sebagai hamba Allah yang mulia. ${ }^{30}$

Kekerasan dalam rumah tangga (KDRT) merupakan tindak kekerasan berbasis gender yang dalam penangananya harus bertitik tolak pada nilai-nilai kemanusiaan, memuliakan sesama dan memberikan manfaat serta menghilangkan kemudharatan bagi manusia. Dalam upaya penanganan istri korban kekerasan dalam rumah tangga harus sejalan dengan tujuan hukum islam yakni perlindungan terhadap terjaminya 5 prinsip utama dalam islam yakni memelihara agama,jiwa, akal, keturunan dan harta, dengan rincian sebagai berikut:

1. Memelihara Agama (hifdz al-din), dalam hal KDRT serangan mental seorang suami terhadap istri sebagai korban sering kali membawa dampak terganggunya integritas keutuhan mental psikologis seorang istri sehingga secara spiritual istri cenderung mengalami kesulitan mengekspresikan rasa syukur sehingga kemampuan untuk menjamin relasi dengan pencipta menjadi berkurang.

2. Pemeliharaan jiwa (hifdz al-nafs), kekerasan terhadap martabat kemanusiaan seperti halnya perilaku KDRT merupakan tindakan diskriminasi yang mengarah pada tindakan intervensi kepada pihak yang dilemahkan. Sesungguhnys dalam Rumah Tangga tugas seorang suami yaitu memberi bimbingan dengan perlakuan yang baik terhadap istri dan anak, bukan melakukan tindakan kesewenangan atau pengekangan terhadap jiwa seseorang.

30 Mufidah, Psikologi Keluarga Islam Berwawasan Gender (Malang: UIN-Maliki Press, 2013),161. 
3. Pemeliharaan akal (hifdz al-'qal), seorang istri menjadi korban dari tindakan kesewenangan seorang istri di dalam lingkungan rumah tangga sering kali dikekang kebebasanya sebagai individu yang merdeka, gangguan psikologis seringkali seringkali menyebabkan seseorang kehilangan kemampuan daya berpikirnya sehingga tidak bisa berfikir logis, secara spiritual pun mereka menjadi tidak mampu mengekspresikan emosinya.

4. Pemeliharaan keturunan (hifdz al-Nasl), kekerasan yang dialami istri dalam rumah tangganya tercermin dalam tindakan kekerasan seksual mepun pemaksaan aborsi secara paksa oleh suami hal ini tentu jauh dari prinsip pergaulan hidup dalam rumah tangga yang seharusnya berlandaskan prinsip muashara bil ma'ruf dan musyawarah yang sejatinya harus ditanamkan dalam kehidupan Rumah Tangga.

5. Pemeliharaan Harta (hifdz al-mal wa al-irdh), seorang istri dalam luang lingkup rumah tangga memiliki hak untuk mendapatkan nafkah yang layak dari seorang suami, tindakan penelantaran terhadap istri dan anak-anaknya merupakan tindakan yang tidak bertanggung jawab, karena kewajiban seorang suami untuk menjamin kelangsungan hidup keluarga yang dibawanya.

Dalam islam seorang suami diperintahkan menggauli istrinya secara ma'ruf dengan larangan untuk berbuat kemadhorotan terhadap istri, seperti budi pekerti yang baik, akhlakul karimah dalam bergaul dengan keluarga, dan dalam masyarakat. Dari sinilah masing-masing suami istri mempunyai hak dan kewajiban guna membentuk kehidupan rumah tangga yang sakinah. Apabila dianggap istri berada dibawah kepemilikan suami dan menerima perlakuan intervensi, ancaman maupun perlakuan kasar lainya maka merupakan tindakan kekerasan yang tidak diindahkandalam ajaran islam. 
Kewajiban pemerintah untuk melindungi warga negaranya dari adanya perilaku diskriminatif harus dilakukan secara komprehensif dengan memperhatikan hak-hak yang seharusnya didapatkan istri dalam kehidupan Rumah Tangga, termasuk hak mendapatkan nafkah lahir batin dari suami, hak mendapatkan perlindungan dairi dan hak mendapatkan penghormatan, hak mendapatkan perlakuan yang patut dari suaminya serta hak memperoleh keputusan hokum yang tidak diskriminatif dalam masalah-masalah perceraian, pengasuhan anak dan warisan, dengan tetap menempatkan keadilan dalam posisi tertinggi sebagai upaya terciptanya pergaulan yang baik (mu'asarah bil ma'ruf) dalam lingkungan keluarga serta demi terwujudnya keseimbangan hak dan kewajiban antar suami dan istri tanpa ada rasa intervensi satu sama lain.

\section{KESIMPULAN}

Dalam upaya penanganan istri korban kekerasan dalam rumah tangga harus sejalan dengan tujuan hukum islam yakni perlindungan terhadap terjaminya 5 prinsip utama dalam islam yakni memelihara agama, jiwa, akal, keturunan dan harta. Dalam islam seorang suami diperintahkan menggauli istrinya secara ma'ruf dengan larangan untuk berbuat kemadhorotan terhadap istri, seperti budi pekerti yang baik, akhlakul karimah dalam bergaul dengan keluarga, dan dalam masyarakat. Dari sinilah masing-masing suami istri mempunyai hak dan kewajiban guna membentuk kehidupan rumah tangga yang sakinah. Apabila dianggap istri berada dibawah kepemilikan suami dan menerima perlakuan intervensi, ancaman maupun perlakuan kasar lainya maka merupakan tindakan kekerasan yang tidak diindahkandalam ajaran islam. 
Kewajiban pemerintah untuk melindungi warga negaranya dari adanya perilaku diskriminatif harus dilakukan secara komprehensif dengan memperhatikan hak-hak yang seharusnya didapatkan istri dalam kehidupan Rumah Tangga, termasuk hak mendapatkan nafkah lahir batin dari suami, hak mendapatkan perlindungan dairi dan hak mendapatkan penghormatan, hak mendapatkan perlakuan yang patut dari suaminya serta hak memperoleh keputusan hokum yang tidak diskriminatif dalam masalah-masalah perceraian, pengasuhan anak dan warisan, dengan tetap menempatkan keadilan dalam posisi tertinggi sebagai upaya terciptanya pergaulan yang baik (mu'asarah bil ma'ruf) dalam lingkungan keluarga serta demi terwujudnya keseimbangan hak dan kewajiban antar suami dan istri tanpa ada rasa intervensi satu sama lain.

\section{DAFTAR PUSTAKA}

Abdurraof. Al-quran dan ilmu Hukum. Jakarta: Bulan Bintang,1970. As-Sa'di, Asy-Syaikh Abdurahman bin Nashir. Taisirul Karimirrahman. Damaskus: Dar al-Fikr.

Ali, Zainuddin, Hukum Perdata Islam di Indonesia. Jakarta: Sinar Grafika, 2006.

Anarto, Apri. Lanskap Hasrat dan Kekerasan. Yokyakarta, Jendela.

Asmuni, Mth. "Upaya Pemikiran Al-Maqashid (Upaya Menemukan Fondasi Ijtihad Akademik yang Dinamis)", Al Mawarid, Edisi XIV, (2005).

Bakri, Asafri Jaya, Konsep Maqashid al-syari'ah menurut al-syatibi. Jakarta: PT Raja Grafindo, 1996.

Dermawan, Andy, "Marital Rape Dalam Perspektif Hukum Al-Quran", Dalam Mochammad Sodik, Tela'ah Ulang Wacana Seksualitas,Cet I. PSW IAIN Sunan Kalijaga, Depag RI Dn McGill-IISEP-CIDA, Yokyakarta, 2004

Djamil, Fathurrahman. Filsafat Hukum Islam. Jakarta: Logos Wacana Ilmu,1999.

Djannah, Fathul Dkk. Kekerasan Terhadap Istri. Yokyakarta: LkiS.

al-Banna, Gamal. Ushul al-Syari" $a h$. Kairo: dar al-Fikr al-Islami, 2006.

Idrus, Nurul Ilmi. Kekerasan Dalam Rumah Tangga. 
Mawardi, Ahmad Imam. Fiqh Minoritas fiqhal-Aqlliyat dan Evolusi Maqashid al-Syari"ah dari konsep kependekatan. Yogyakarta: Lkis, 2010.

Milda, Marlia. Marital Rape Kekerasan Seksual terhadap Istri. Yogyakarta: PT.Lkis Pelangi Aksara, 2007.

Mufidah. Psikologi keluarga Islam berwawasan Gender. Malang: UINMaliki Press, 2013.

Idrus, Ahmad Musyahid. Urgensi Filsafat Hukum Islam dalam Penetapan Hukum Islam: Kajian Filosofis terhadap Persoalan Hukum Kontemporer. Makasar: Allauddin University Press, 2014.

Nurhayati, Elli. Panduan untuk pendamping korban kekerasan. Yokyakarta: Rifka Anisa, 2000.

Subhan, Zaitunah. Kekerasan Terhadap Perempuan. Yokyakarta: PT.LkiS Pelangi Aksara. 